\title{
Travel Writing and Sexuality: Queering the Genre
}

\author{
Churnjeet Mahn
}

University of Strathclyde

Sex and travel are hardly unfamiliar bedfellows; indeed, access to sex, especially when it is tabooed, has often been an impetus to travel in the first place. Yet if a significant body of research has been produced around gender and travel writing, especially on women's writing, sexuality has seldom been an important criterion in the scholarly analysis of travel writing past and present. Apart from a few notable exceptions (Littlewood 2001; Phillips 2002; Jacobs 2012), the analysis of sexuality has usually been subsumed into discussions of gender, whilst 'queer' in travel writing studies is often used simply as a shorthand for gay and lesbian identities rather than as a methodological tool through which to approach the description of transgressive, alternative, or non-normative sexualities. Yet the burgeoning field of queer theory has the potential not only to create new inroads into well-known subjects, but also to contribute to an ongoing discussion of how bodies, identities and subjects are rendered and represented in the act of writing. In this chapter, accordingly, I explore some of the ways in which queer studies might productively intersect with travel writing studies. Rather than offering a comprehensive account or genealogy of queer travel writing, my aim is to highlight some key texts and moments where queer lives become more visible in travel writing.

Although defining queer theory is notoriously difficult, it is possible and important to identity some core concerns that are relevant for scholars of travel writing. Queer theory is interested in the way 'normal' categories, especially in sexuality, are produced and how nonnormative sexualities are pushed out of cultural recognition and sanction through legal 
practices (such as the criminalization of sodomy), discursive structures (such as the vilification of homosexuality), and the privileging of certain lifestyles and social customs (such as heterosexuality). Foucault's seminal study, The History of Sexuality (1976), analysed the way discursive structures such as the 'homosexual' were produced through legal, medical and ideological discourses. There is nothing natural or inevitable about sexuality for queer theorists; rather, the labelling of sexuality is a way to create types of legitimate and illegitimate bodies. David Halperin defines the queer as: "whatever is at odds with the normal, the legitimate, the dominant. There is nothing in particular to which it necessarily refers. It is an identity without an essence. "Queer" [...] describes a horizon of possibility whose precise extent and heterogeneous scope cannot in principle be delimited in advance' (Halperin 1997: 62, emphasis in the original). Halperin, Judith/Jack Halberstam, Judith Butler and Annamarie Jagose are amongst a group of critics who have challenged the operation of gender and sexuality in Western cultures through case studies of subjects and groups whose lives are pushed to the edge of acceptability. Queer theorists are consequently most concerned with lives and subjects at the margins of visibility and viability, often deploying the language of (im)possibility and (il)legibility to reflect the way queer lives are always present but often hidden from view due to the pressures in society to conform to norms. Halperin's 'horizon of possibility' is an imperative to create new forms of being and interaction that actively resist dominant discourses, and to identify a history of sexual dissidence. It is easy to imagine why travel writing can be a perfect vehicle for the queer: travel has a long association with subjects crossing conventional borders and boundaries, and the margin and periphery are travel writing staples.

Lesbian, gay, bisexual, transexual and queer (LGBTQ) has become an umbrella term for a collection of identities whose commonality is a challenge to 'normal' sexuality. However, it would be erroneous to assume that there is a single, collective vision within these 
groups, or that all people who identify as LGBT or Q are sympathetic to recent theoretical and critical interpretations of queerness. 'Queering' travel involves interrogating how the genre helps to produce, and sometimes challenge, knowledge and understanding about sexuality. Rather than referring to a discrete body of knowledge, it involves the disruption and questioning of heteronormative paradigms. Queering the travel writing canon is to some extent a matter of identifying and critiquing moments when the genre works in culture to promote and enforce normative (hetero)sexuality; and it is a project especially concerned to recover and explore moments in which heteronormative structures and relationships are queried or undermined through travel or travel writing. The most obvious focus here is perhaps the recent growth in openly gay and lesbian travel writing, yet I would argue that the genre has always had queer undercurrents.

A comprehensive history of these aspects of the travel writing tradition is beyond the scope of this chapter, but in the first section I offer some glimpses into queer moments in Anglophone travel and travel writing prior to the rise of LGBTQ-identified literature and politics. I roughly date this phase from the late eighteenth century, which witnessed a rise in recreational or touristic travel, and consequently a greater exposure to different models of sexuality around the Mediterranean. Part of my argument is that in this pre-LGBTQ phase of writing it is possible to identify a loose collection of literary threads which challenged sexual norms and categories without necessarily belonging to a cohesive movement. While same-sex attraction features strongly in this, it is not an exclusive feature of the way writers challenged sexuality. I then move on to discuss the comparatively recent appearance of openly LGBTQ travel writers, addressing some of the issues raised by such categorizations and by the identity politics related to them. In particular, I explore the frequent slippage between the terms 'LGBTQ' and 'queer' in popular culture, community groups, policy discussions and even some recent scholarship. Here, however, I want to consider whether gay and lesbian 
travel writing is always queer travel writing. While being a lesbian might be queer because of the challenge to heteronormative sexual categories, it also comes with an identity politics which queer theory resists. In the final section I explore what can be at stake when LGBTQ writers project Western sexual categories on to other cultures; and here, mindful of recent scholarship that brings queer studies into conversation with postcolonial studies, I look especially at recent gay travellers in Islamic countries and contexts.

\section{Queer Lives, Queer Journeys}

In the late eighteenth and early nineteenth centuries, popular Gothic novels such as Matthew Lewis's The Monk (1796), prurient accounts of Lord Byron's travels and the satirical prints of figures like Thomas Rowlandson helped make the Mediterranean a region strongly associated with taboo sexual practices such as incest, sodomy and pornography. William Beckford was effectively forced into exile for his homosexuality in the 1780s; travel for him was not only a creative activity, but a means of sexual access. Shelley and Byron fashioned themselves as anti-establishment figures, something that extended to their views of sexuality, especially 'Greek love'. Before travelling to the Balkans for the first time, Byron wrote, 'In England the vices in fashion are whoring \& drinking, in Turkey sodomy \& smoking. We prefer a girl and a bottle, they a pipe and a pathic' (Marchand 1982: 36). Apart from his early youth, the vast majority of Byron's same-sex contact was in the Ottoman regions of the Mediterranean, especially Greece. 'Greek love' was an aesthetic materialised through the bodies of the Greek boys and men he had sexual relations with. Hellenism and Orientalism offered the perfect imaginative and geographical frameworks for Byron's sexuality.

An important influence here was ancient literature, especially that of the Greeks. The 'Classics' offered the historical distance and cultural credentials to play out different visions 
of sexual, moral and ethical standards. In the eighteenth, nineteenth and early twentieth centuries, the appreciation and study of these texts often provided evidence of, and served as a catalyst to, non-heteronormative lives. For a highly selective intellectual elite, the Classics offered a cultural acumen that could begin to legitimate an interest in certain culturally tabooed and prohibited practices. This interest in Greece peaked in the late nineteenth century when a growing number of British and German writers and scholars were actively travelling to Greece to research the diversity of sexuality and sexual practice in ancient and archaic Greek culture. Not all of them were men. Jane Ellen Harrison, the Cambridge Classicist whose work led to charges of 'Sapphic' interest, looked for evidence of pre-patriarchal social structures in Greece's archaic period and had a keen interest in sexuality. Investigating early rituals and forms of religion, Harrison's challenge to patriarchal and heteronormative sexualities came through her anthropological and archaeological work in an era of Greek history that existed before/behind imperial Athens. She deliberately used the distance and opacity of archaic Greece as a metaphor for the impossibility of understanding a social structure so radically different from contemporary patriarchies. Harrison had an important impact on a series of feminists and travellers interested in Greece, especially the young Virginia Woolf. Her own observations of her travels were summarised in Reminiscences of a Student's Life (1925) where she catalogued life at the male-dominated British School at Athens. Harrison's queerness goes beyond speculations around her sexuality: it belongs to a realm of interest and inquiry that brought a series of intellectuals to Greece as a way of revealing alternative social frameworks that accommodated more fluid and flexible models of sex and desire.

The art critic Walter Pater (1839-1894), the human rights activist Edward Carpenter (1844-1929), Oscar Wilde (1854-1900) and the sexologist Magnus Hirschfeld (1868-1935) were all men whose travel informed their personal and intellectual commitment to 
homosexuality. While Pater and Wilde explored the theme of 'Greek love' in their writing and aesthetics, Carpenter and Hirschfeld were part of an early vanguard of Western European activists that did not see lesbian or gay sexuality as a state of inversion or perversion. As the Nazis rose to power in Germany, Hirschfeld undertook a world lecturing tour to avoid discrimination, a tour that provided the foundations for Men and Women: The World Journey of a Sexologist (1935). As a minor celebrity at the time, Hirschfeld became a magnet for sexual information and discussion during his travels. From seeing fertility customs in Java to observing forms of matriarchy in Bali, he curated a world of sexual variety and difference in his travel writing, albeit with a tendency towards impressionism rather than objective study. However, figures such as Hirschfeld were exceptional in this period. Literary censorship, fears of arrest, and social stigmas were strong enough to ensure that most personal accounts of sexual difference or deviation remained private and hidden.

As interest in the Classics waned at the beginning of the twentieth century, writers interested in non-heteronormative lives and practices migrated to new forms of artistic practice, creating new lines of queer inquiry. Modernism offered a fertile territory for queer writing and politics in fiction, although its presence in travel writing is less pronounced. Explorations of strangeness and estrangement were bound up in the travel, writing and philosophy of a number of key figures. The poet H.D., Virginia Woolf, Gillian Bouras, Gertrude Stein, E.M. Forster, André Gide, and Djuna Barnes were amongst a group of writers for whom literary and sexual experimentation went hand-in-hand. One of the most striking examples of this is Virginia Woolf's novel Orlando (1928), which playfully explores bisexuality through a historical fantasy focussed on travel. Yet queer themes are mostly explored in fiction in this period, rather than in non-fictional, ostensibly factual travel writing, since fiction offered at least a partial veil against legal or personal challenges in connection with sexual deviance or difference. While travel writers in the period may have been sexually 
experimenting abroad to avoid the prying gaze of friends and family, the status of travel writing as an authentic or real account of experience offered potentially dangerous exposure.

This is not to say that there are no canonical examples of travel writing in the early to mid-twentieth century which tackle alternative forms of sex and sexuality. In the 1950s, the Beats brought together a group of intellectuals for whom sexual and literary experimentation was hardwired into travel and a politics of spontaneity that aimed to bypass stale traditions. Sex and sexuality was more than just a lifestyle for the Beats: it was part of their selffashioning and their creative manifesto. Jack Kerouac's On the Road (1957) has been hailed as a counter-cultural text partially because of its use of travel as a pseudo-spiritual state of being that reflects a disenchantment with the categories of home and tradition. However, one wonders whether the text would enjoy the same cult status if it more clearly articulated Keroauc's frequent slippage between homosocial and homosexual relations with the men he meets. To put it simply, would it be a cult text if the principal protagonists were openly gay? Unlike Allen Ginsberg and William Burroughs, who were relatively open about their homosexual encounters, both Kerouac and Neal Cassady primarily identified as heterosexual men yet had occasional sexual contact with men. However, many of the homosexual acts which should appear in On the Road are self-censored by Kerouac in favour of ruminations on his relationship with Cassady, the road, and his writing. While spontaneity and impulsivity are important to the Beats in bypassing the mundane orthodoxy of societal expectations, Kerouac fails to blend a convincing version of bisexuality through the omission of his own sexual experimentation. In addition to this, the relative immobility of the women in the text demonstrates the inscription of patriarchal structures within the Beats' aesthetic.

While there may have a been a growth in writing about queer subjects and cultures from the nineteenth century onwards, it would be erroneous to assume that each successive generation or group of writers represent a chronological pin on an easy-to-trace trajectory of 
growing resistance to hetero-patriarchal structures and values. For example, while the Beats hold an iconic status partially based on their counter-cultural values, their representation of gender and gender norms reproduced its own misogyny and discrimination. These were men using male privilege to legitimise their crossing of selective boundaries. However, the social agitation around civil rights in the 1960s and 1970s facilitated the greater visibility of lesbian and gay cultures, as well as developing a sense of what identifying oneself as 'gay' or 'lesbian' might look like or mean in a positive, rather than a negative, light. The greater legal and social tolerance thus accorded non-normative lives in turn allowed the appearance of travel accounts by openly LGBTQ writers, many of whom were expressly concerned to explore in their travels a range of queer identity labels and sub-cultures.

\section{Identifying Bodies: LGBTQ Travel Writing}

From the mid-twentieth century, it is possible to identify a growing number of travel writers who can fall under the umbrella term of 'LGBTQ writing'. These are travellers who were either open about their sexuality, or who were consciously aware of LGBTQ politics, even if they themselves had a difficult relationship with the movements. For example, Bruce Chatwin was bisexual and hid his sexuality, but despite this we can read him in a genealogy of writers for whom the awareness of LGBTQ politics and lives had an impact on how they positioned themselves and their work. (In Chatwin's case it was firmly in the closet.) Christopher Isherwood reflected on his travels as a gay man later in his life, at a time when attitudes towards sexuality had softened. However, Edmund White is arguably the first mainstream travel writer to foreground his experiences as a gay man throughout his career. In his pioneering travelogue States of Desire: Travels in Gay America (1980) - written in the aftermath of the Stonewall Riots and subsequent gay and lesbian political agitation in North 
America - White is sensitive to the ways in which the lesbian and gay communities he travels through inevitably merge the sexual and the political. The volume has now a poignant, elegiac aspect; White's narrative ends just before the AIDS crisis, which devastated most, if not all, of the communities he travelled through.

While White stands as a major figure in gay travel writing, there are relatively few figures who have achieved the same range or scope in their travelogues. Kadushin's volumes Wonderlands: Good Gay Travel Writing (2004) and Big Trips: More Good Travel Writing (2008) have been important for collecting the work of contemporary gay male writers who have produced shorter pieces of travel writing. However, the genre is arguably not keeping pace with the rate of development in gay and lesbian tourism. This is not to say that issues of sexuality are not dealt with; indeed, in many ways the travel writers following in White's footsteps have reached wider audiences through embracing a range of genres from comedy to memoir. White's literary descendants have exported their mixture of autobiography, humour, and human observation of gay life in America and France to forms such as creative nonfiction; see, for example, David Sedaris's Me Talk Pretty One Day (2001) or David Rakoff's Don't Get Too Comfortable (2005). Yet openly gay travel writing remains a very small strand of this perennially popular genre.

As with many other gay and lesbian literary genres, lesbian travel writing is less visible than its gay male counterpart. Like women's travel writing in general, at least until the recent scholarly recovery of this branch of the genre, lesbian travel writing has been neglected and excluded from the mainstream canon. In overviews of travel writing, 'queer' is often reduced to 'gay and lesbian' which, in turn, is often reduced to just 'gay'. While magazines, zines and blogs have circulated accounts of lesbian and gay travel, there is a curious deficiency of published travel accounts by women. This is symptomatic of a more general lacuna or absence. Martha Vicinus (2004), Annamarie Jagose and Terry Castle are 
amongst a group of critics who have theorised the ways in which lesbian desire has been rendered invisible in cultural histories, to become, as Jagose puts it, 'utopic' (1994: 2) - in the sense of 'being of no place' - or 'apparitional', in Castle's more controversially phrasing (1993: 30). Drawing on the work of French feminists such as Luce Irigaray, Vicinus, Jagose and Castle, amongst others, have led a movement towards thinking about the lesbian as a figure who stands outside dominant patriarchal control, thereby circumnavigating phallocentric order. These studies have been used to sketch out a theoretical history of lesbian lives in Western culture which strategically uses lesbian 'invisibility' to work outside traditional histories or genealogies.

A selection of lesbian writers are brought together in Gillian Kendall's edited volume Something to Declare: Good Lesbian Travel Writing (2009), an important output of the University of Wisconsin's active collation of new lesbian and gay travel writing. The themes of visibility and invisibility are explored by one of the most famous contributors to the volume, Lucy Bledsoe. The author of a number of novels and travel accounts, Bledsoe offers in 'Fruits at the Border' an account of a journey with her partner through Chile and Argentina. Border crossings are used as a metaphor for the ways in which people can 'pass' unchecked, and for what triggers 'detection' and possible detention. 'In most cultures', she writes, 'women are perceived as less threatening than men or as being inconsequential altogether, which allows us to slip across different kinds of borders, not just international ones' (Kendall 2009: 192). Approaching a border Bledsoe observes: 'Granted, as middleaged women, we were quite invisible in that culture, but wanted to remain that way for the most part [...] [O]ur being lesbians did add an additional layer of risk we didn't need to play with' (Kendall 2009: 196). Despite this, Bledsoe lists a range of women who detect something different about her relationship with her travelling companion, and who offer additional help. The 'fruits' at the border refer to her own anxieties about detection. Apples 
are not allowed to cross the border, but Bledsoe and her partner have little access to fresh fruit, so decide to smuggle some into Chile. While her partner condones their concealment, Bledsoe succumbs under her own paranoia and fear of discovery, declaring her contraband to border control.

While the piece is humorous and light-hearted, Bledsoe points to the complex ways in which travellers can live in fear and paranoia about their own sexual disclosures and the consequences of being labelled as a lesbian, especially in cultures with unsympathetic legislation. Bledsoe offers a nuanced layering of identity: she is attuned to the complex ways in which ethnicity, nationality, gender, and sexuality impact the way bodies move through space. She can trade on the privilege of her ethnicity and nationality, be aware of the vulnerabilities posed by her gender, and selectively disguise her sexuality. Immigration controls become an emblem for the way states regulate a body's access to recognition or legality. Yet the real level of surveillance and detection in Bledsoe's piece is not at the border, but at the level of self-censorship through the internalisation of homophobic discourses. However, one issue Bledsoe does not address is to what extent there is a shared understanding of what a 'lesbian' is across different cultures; this is a topic I shall come back to in my final section.

The growing confidence of lesbian and gay writers has facilitated alliances with other bodies which failed to conform. A section of queer theory has focussed on what happens to bodies when the basic operation and realisation of gender fails, not as an aesthetic experiment but as a basic social and biological reality (Butler 1993). The growing visibility of transgendered subjects in literature coincided with surgical and cultural explorations of the body, and a growing appreciation of the complex discontinuities that can be in play between biological and lived gender. Cisgender is a term recently adopted to describe a person where there is no social conflict between biological sex and lived gender (for example, a person 
identifying as a woman who was also biologically born as a woman). The agitation around this term partially reflects a desire to develop a more sophisticated vocabulary to describe the ways in which bodies and identities operate within 'normal' or 'not normal' categories.

These issues are relevant to the career of one of Britain's most famous travel writers, Jan Morris, who was born as James Morris in 1926. An account of her life, travels and transition from male to female was published as Conundrum (1974). The memoir uses travel to trace her movement between places and between genders. For Morris sexuality is an external experience rather than an embodied state: 'I have never doubted, though, that much of the emotional force, what the Welsh call hwyl, that men spend in sex, I sublimated in travel - perhaps even in movement itself, for I have always loved speed, wind and great places' (Morris 2002: 88). Yet despite being a comparatively rare account of the transsexual journey, Conundrum is a problematic text for many critics. At issue is Morris's attitude to Africa, where s/he went to have her gender realignment performed. A self-confessed 'child of imperial times' (Morris 2002: 109), Morris frequently applies to the continent an imagery of blackness and darkness, something Marjorie Garber (2011) has described as Orientalist and Carol Riddell has called 'embarrassing' (2006: 152). Moreover, Morris seldom reflects critically on the way being British facilitates her privileged travels, and the way it provides her access to select clinics for surgery. As a result, Conundrum is for queer theorist Judith Halberstam 'less [...] a representative narrative [of transgender experience] and more [...] a caution against detaching the metaphors of travel and migration from the actual experience of immigration in a world full of borders' (1998: 169-70).

As this suggests, LGBTQ identities are not necessarily deviant, radical or progressive in the positive senses of these terms. They can reproduce sexism and racism in mundane forms through reproducing and internalising other forms of cultural stereotypes and orthodoxies. Equally, while gay and lesbian writing may be categorised as 'queer' through its 
fundamental challenge to heterosexuality as the only legitimate model for sexual relationships, it is constantly in danger of developing its own orthodoxies and exclusive categories (for example, can a bisexual woman be a lesbian?). The identity politics behind LGBTQ movements has been important for securing rights and fostering a community within which LGBTQ identification is a primary issue and desire. Yet these identities may also be more rigid and more limiting than the earlier, more complex and contradictory identity formations which went under the umbrella term 'queer'. The latter is an identity label which categorically refuses straight privilege, passing or ambiguity; its queerness is more definite and defiant.

\section{States of Conflict: Transnational Sexualities}

In the past ten years, scholars have been paying increasing attention to the intersection of queer theory and postcolonial studies, bringing these two fields into dialogue to critique the way contemporary discussions of sexuality, especially queer sexualities, are dominated by Eurocentric and Anglo-American definitions and categories which efface alternative discourses of desire and difference. Rather than assuming that the West is more sexually liberal and progressive than the rest of the world, attention has been increasingly paid to other, non-Western histories of sexuality There has also been significant debate about whether the terms 'lesbian' and 'gay' have a transnational significance and meaning or if their use always returns back to essentialised Western categories for identity (Vanita 2002; Gopinath 2005; Bauer \& Mahn 2014). 'Queer' has been used by critics as a more open way to understand non-heteronormative experiences and communities, thereby avoiding the narrow labelling of 'lesbian' or 'gay' practices which are not easily translatable across the globe. In this spirit, Jasbir K. Puar (2002) has offered a useful analysis and overview of 
modern tourism's relationship to issues of transnational sexuality. In her discussion, she also insists on the inadequacy of an older scholarly model of 'intersectionality', prevalent since the 1980s, which assumed that identities (queer and otherwise) could be construed in terms of the inter-relationship of supposedly discrete, fixed categories such as race, class and gender. As Puar writes, 'There is no entity, no identity, no queer subject or subject to queer, rather queerness coming forth at us from all directions, screaming its defiance, suggesting a move from intersectionality to assemblage, an affective conglomeration that recognizes other contingencies of belonging' (2007: 211). The notion of 'assemblage' here derives from French theorists Deleuze and Guattari (1987), and is intended to convey the far more complex ways in which subjects actually negotiate a multitude of experiences that cannot be disaggregated or reduced to identity politics.

Notwithstanding the theoretical enquiries outlined above, there is still relatively little work on queer travel writing alongside the issues of race and faith. However, an important collection that brings together these themes is Michael Luongo's Gay Travels in the Muslim World (2007). Crossing national, racial and ethnic boundaries, this landmark volume has assembled a range of largely gay-identified men to discuss their same-sex experience in the context of Islam. Histories of non-heteronormative practices and lives in Islamic contexts have highlighted the inadequacy of identity-based categories such as 'gay' and 'lesbian', both of which carry their own associations and histories (Ioannides 2014; El-Rouayheb 2005). To what extent, therefore, can the terms 'gay' and 'lesbian' carry a trans-faith significance (Gopinath 2005; Bauer \& Mahn 2014)? Travelling to Mauritania with the US Peace Corps, Jay Davidson meets men who are sexually interested in him, but for whom the future involves marriage with a woman and children. Same-sex relations in this context are not necessarily a secret or a contradiction; they are an extension of sexuality and operate in concert with more conservative national prescriptions about the composition of a family. 
Confused by the sexual attention two men are paying to him and a female Peace Corps volunteer, Davidson observes, 'it did make we wonder about how they saw their own sexuality. It was my first indication that people elsewhere in the world are living and dealing with a more fluid definition of sexuality than the one we experience in the United States' (Luongo 2007: 4). Reflecting on his fellow travellers he comments, 'I have heard people say, "We don't have homosexuals in Mauritania." Most Americans laugh at what they perceive to be such a naïve and absurd statement' (Luongo 2007: 8). These assumptions demonstrate the way sexual 'progress' is often measured by Western standards: the allegation of naiveté simply becomes a way of suggesting that Islamic cultures are in the infancy of understanding the complexity of sexuality.

In this way, several of the pieces in Luongo's anthology project Western sexual categories on to the very different cultures of the Middle East. Elsewhere, many of these travel accounts exhibit longstanding Western prejudices about Islam and deploy familiar tropes of Orientalism, especially around the issue of sexual excess/access in the region. Richard Ammon identifies generations of (in)famous travellers and ordinary tourists for whom North Africa represented sex, mystery and access to young men for the right price (Luongo 2007: 92). The growing visibility of lesbian and gay travel has had a detectible influence; Martin Foreman comments on the way gay porn has created new transnational markets for consuming homosexuality (Luongo 2007: 20). Yet despite the prevalence of stereotypical East/West, Islamic/Non-Islamic binaries in the collection, there are a number of accounts describing other kinds of border crossings. As discussed earlier, travel can lead to the possibility of living more open lives. Ethan Pullman uses the literal meaning of the word 'intifada' - 'to wake up from sleep' (Luongo 2007: 61) - to describe his move from being a closeted Palestinian Muslim to being an openly gay man in North America. The film-maker Parvez Sharma uses his transnational journeys as a way of thinking about how travel and 
sexuality can be framed as a form of activism. He ends with an imperative: 'Let's together travel gay - through the richness of Islam. Let's get our hands dirty and let's please manufacture dissent' (Luongo 2007: 109).

Sexuality, dissent and travel are natural companions in writing, illuminating the varied and messy ways in which bodies and discourses come into intimate contact. Queering travel writing, we acknowledge and promote the genre's potential to destabilize cultural and social norms, and we nuance our discussion of that destabilizing tendency. The challenge for future studies of queer travel writing is twofold: identifying more examples of queerness in mainstream texts to generate new readings, and avoiding the temptation to conflate 'queerness' with minority LGBTQ identities.

\section{Bibliography}

Bauer, H., and Mahn, C. (2014) 'Introduction to Special Issue on Transnational Lesbians', Journal of Lesbian Studies, 18(3): 203-8.

Butler, J. (1993) Bodies That Matter, London: Routledge.

Castle, T. (1993) The Apparitional Lesbian: Female Homosexuality and Modern Culture, New York: Columbia University Press.

Deleuze, G. and Guattari, F. (1987) A Thousand Plateaus: Capitalism and Schizophrenia, Minneapolis: University of Minneapolis Press.

El-Rouayheb, K. (2005) Before Homosexuality in the Arab-Islamic World, 1500-1800, Chicago: University of Chicago Press.

Garber, M. (2011) Vested Interests: Cross-Dressing and Cultural Anxiety, New York: Routledge.

Gopinath, G. (2005) Impossible Desires: Queer Diasporas and South Asian Public Cultures. Durham: N.C.: Duke University Press.

Halberstam, J. (1998) Female Masculinity, Durham, N.C: Duke University Press.

Halperin, D. (1997) Saint Foucault: Towards a Gay Hagiography, Oxford: Oxford University Press. 
Ioannides, G. (2014) 'Queer Travels: Intersections for the Study of Islam, Sexuality, and Queer Theory', in Y. Taylor and R. Snowdon (eds), Queering Religion, Religious Queers. New York: Routledge.

Jacobs, J. (2012) Sex, Tourism and the Postcolonial Encounter, Aldershot: Ashgate.

Jagose, A. (1994) Lesbian Utopics, New York: Routledge.

Kadushin, R. (ed.) (2008) Big Trips: More Good Gay Travel Writing, Madison, WI: University of Wisconsin Press.

Kadushin, R. (ed.) (2004) Wonderlands: Good Gay Travel Writing, Madison, WI: University of Wisconsin Press.

Kendall, G. (ed.) (2009) Something to Declare: Good Lesbian Travel Writing, Madison, WI: University of Wisconsin Press.

Lewis, R. (1996) Gendering Orientalism: Race, Femininity and Representation, New York: Routledge.

Littlewood, I. (2001) Sultry Climates: Travel and Sex, London: John Murray.

Luongo, M. (ed.) (2007) Gay Travels in the Muslim World. New York: Harrington Park Press.

Marchand, L.A. (ed.) (1982) Lord Byron: Selected Letters and Journals, Cambridge MA: Harvard University Press. Morris, J. (2002) Conundrum, London: Faber and Faber.

Phillips, R. (2002) 'Travelling Sexualities: Richard Burton's Sotadic Zone', in J. Duncan and D. Gregory (eds), Writes of Passage: Reading Travel Writing. London: Routledge.

Puar, J.K. (2002) 'Circuits of Queer Mobility: Tourism, Travel and Globalization', GLQ: A Journal of Lesbian and Gay Studies, 8.1-2: 101-137.

Puar, J.K. (2007) Terrorist Assemblages: Homonationalism in Queer Times, Durham: N.C.: Duke University Press.

Riddell, C. (2006) 'Divided Sisterhood: A Critical Review of Janice Raymond's The Transsexual Empire', in S. Styker and S. Whittle (eds), The Transgender Studies Reader. New York, Routledge.

Roberts, M. (2008) Intimate Outsiders: The Harem in Ottoman and Orientalist Art and Literature, Durham: N.C.: Duke University Press.

Schiffer, R. (1999) Oriental Panorama: British Travellers in Nineteenth-Century Turkey, Amsterdam: Rodopi.

Vanita, R. (2002) Queering India: Same-Sex Love and Eroticism in Indian Culture and Society, New York: Routledge.

Vicinus, M. (2004) Intimate Friends: Women Who Loved Women: 1778-1928, Chicago: University of Chicago Press.

White, E. (1980) States of Desire: Travels in Gay America, London: Picador. 